\title{
USE OF RESALE PRICE MAINTENANCE BY INTEGRATED MANUFACTURERS: A NEW LOOPHOLE FOR ABUSE OF MONOPOLY POWER*
}

\begin{abstract}
Although price-fixing is illegal per se under the antitrust laws, ${ }^{1}$ Congress has granted immunity from that prohibition to certain resale price maintenance contracts entered into by manufacturers of branded or trade marked goods. ${ }^{2}$ Both the Miller-Tydings and McGuire Acts specifically state, however, that they do not legalize such agreements "between persons, firms, or corporations in competition with each other."' An agreement between a nonintegrated manufacturer and wholesalers or retailers to maintain a resale price on the manufacturer's product is between parties who are not competing on the same functional level of enterprise. The contracts are therefore "vertical" and clearly within the scope of Fair Trade legislation." But when a manufacturer who owns retail or wholesale outlets utilizes resale price maintenance to bind competing retailers or wholesalers, ${ }^{5}$ the practice can be con-
\end{abstract}

*United States v. McKesson \& Robbins, Inc., 122 F. Supp. 333 (S.D.N.Y. 1954).

1. United States v. Socony-Vacuum Oil Co., 310 U.S. 150 (1940); United States v. Trenton Potteries Co., 273 U.S. 392 (1927); Dr. Miles Medical Co. v. Park \& Sons, 220 U.S. 373 (1911).

2. Such contracts are lawful if state law authorizes them as to intrastate transactions and if the product affected is in "free and open competition with commodities of the same general class produced or distributed by others." 50 STAT. 693 (1937), 15 U.S.C. $\$ 1$ (1952) (Miller-Tydings Act); 66 StAт. 632, 15 U.S.C. $\$ 45$ (1952) (McGuire Act). At present, 45 states have Fair Trade laws. For texts of the state statutes, see 2 CCH Trude REG. ReP. III 10,000-15,520.10 (1954).

For discussions of Fair Trade in general consult FTC Report on REsale PutCE Maintenance (1945) (hereinafter cited as FTC Report); Grether, Price Controt. Under Fair Trade Legislation (1939); Fulda, Resale Price Maintenantec, 21 U. Cu1. L. REv. 175 (1954).

3. "Nothing contained in paragraph (2) of this subsection shall make lawful contracts or agreements providing for the establishment or maintenance of minimum or stipulated resale prices on any commodity referred to in paragraph (2) of this subsection, between manufacturers, or between producers, or between wholesalers, or between brokers, or between factors, or between retailers, or between persons, firms, or corporations in competition with each other." 66 STAT. 632, 15 U.S.C. $\S 45$ (1952) (§ 5(a)(5) of the McGuire Act). The second proviso of $\S 1$ of Miller-Tydings is almost identical. 50 STAT. 693 (1937), 15 U.S.C. $\$ 1$ (1952).

4. See 98 Cong. REc. 4951 (1952). See also Schwegmann Bros. v. Calvert Distillers Co., 341 U.S. 384, 389 (1951) (dictum) ; Lionel Co. v. Grayson-Robinson Stores, 27 N.J. Super. 54, 60, 98 A.2d 623, 626 (1953) (same).

5. In response to the limitation on Fair Trade imposed by the Supreme Court in Schwegmann Bros. v. Calvert Distillers Corp., 341 U.S. 384 (1951), the McGuire Act broadened the immunity of resale price maintenance contracts from the antitrust laws by 
sidered "horizontal" in nature and outside the exemption from the antitrust laws provided by Miller-Tydings and McGuire. ${ }^{\circ}$

Nevertheless, in the recent case of United States $\%$. McKesson \& Robbins, Inc., ${ }^{7}$ a district court held that a showing that defendant qua wholesaler competed with independent wholesalers in the distribution of commodities manufactured by defendant ${ }^{8}$ did not automatically prevent Mickesson from entering into resale price contracts with such wholesalers." Since the agreements were capable of operative effect in both a "horizontal" and a "vertical" direction, the court was unwilling to find either label more apposite than the other or to pin its decision on factors having little more than semantic

validating rights of action created by state nonsigner laws. Such nonsigner laws ordinarily provide that "willfully and knowingly advertising, offering for sale, or selling any commodity at less than the price or prices prescribed in such contracts or agreements whelher the person so advertising, offering for sale, or selling is or is not a party to such a contract or agreement" is actionable at the suit of any person damaged thereby. (Emphasis added.) See 2 CCH Trade Reg. Rep. II 10,000-15,520.10 (1954). Forty states now have such nonsigner provisions. 1 CCH TRADE REG. REP. I 3003 (1954). Contracting parties and those bound to resale price agreements by state nonsigner provisions are treated without distinction for purposes of the discussion that follows.

6. The problem has been considered by the courts, Federal Trade Commission, and legal writers with varying results. Eastman Kodak Co., 3 CCH TRAnE REs. REP. II 11,527 (FTC 1953) (contract invalid if hearing examiner finds actual competition between the integrated manufacturer's outlets and the bound outlets); Doubleday \& $\mathrm{Co}, 3 \mathrm{CCH}$ TRADE REG. REP. If 11,515 (FTC 1953) (contracts invalid if hearing examiner finds that defendant contracted in his capacity as distributor); Eastman Kodak Co. v. Aljan Camera Co., 133 N.Y.S.2d S0S (Sup. Ct. 1954) (contract enforceable).

For discussions which reach different conclusions from those arrived at here, see Weston, Resale Price Maintenance and Market Integration: Fair Trade or Foul Play?, 22 Geo. Wash. L. Rev. 658 (1954); 54 CoL. L. Rev. 2S2 (1954); Note, Fair Trade and Horizontal Prize Fixing: Their Status Since the Second Schwegmomn Case, 63 YaLE L.J. 538, 54446 (1954).

7. 122 F. Supp. 333 (S.D.N.Y. 1954).

8. At its Bridgeport plant McKesson manufactures and packages over 400 different items consisting of drugs, pharmaceuticals, cosmetics, and toilet preparations. In 1923 the corporation began acquiring control of wholesale drug companies and has continued to acquire them. Defendant now conducts a nationwide wholesale drug business, operating 74 wholesale drug divisions located in 35 states. Its wholesale business now accounts for about $65 \%$ of its total sales volume. United States v. MfcKesson \& Robbins, Inc, $122 \mathrm{~F}$. Supp. 333, 334 (S.D.N.Y. 1954); Weston, supra note 6, at 669 n.37.

Defendant's answer admitted that its manufacturing division sells price-fixed products to independent wholesalers in 7 localities where the "trading areas" of MrcKesson's wholesale divisions "overlap" the "trading areas" of independents. Such sales amounted to $\$ 283,462$ in fiscal year 1951-1952. In addition, Mckesson price-fixed products are sold directly by defendant's manufacturing divisions to retailers in territories also served by independent wholesalers. Furthermore, McKesson's wholesale divisions are permitted to sell directly to competing wholesalers. Sales of this latter category amount to approsimately $\$ 200,000$ annually. United States v. $\mathrm{XicKesson} \mathrm{\&} \mathrm{Robbins,} \mathrm{Inc.,} \mathrm{supro} \mathrm{at} 335$.

9. The Government's motion for a summary judgment and its request for an injunttion restraining price stipulation affecting competing wholesalers were denied. 
significance. ${ }^{10}$ Instead, it held that a factual showing of some additional injurious effect upon competition beyond that inherent in the use of resale

10. United States v. McKesson \& Robbins, Inc., 122 F. Supp. 333, 337 (S.D.N.Y. 1954). The court's realistic analysis represents a notable advance over the literalism that has plagued the Federal Trade Commission in dealing with the problem. In Doublectay \& Co., 3 CCH Trade Reg. Rep. I 11,515 (FTC 1953), a majority of the Commission stated its test as follows: "When negotiating the fair trade agrecments with retailers was respondent acting in its capacity as manufacturer-publisher or in its capacity as retailer " In other words, it is necessary to study the particular agreement, examine its form, economic purpose, intent and effect and then decide whether it is . . vertical or horizontal ...." Id. at p. 12,493. However, the Commission reversed itself and the Doubleday test was overruled sub silentio in Eastman Kodak Co., 3 CCH TraDE REc. REp. If 11,527 (F.T.C. 1953). In the latter case, it was held that Kodak's contracts would be invalid if the examiner found competition between Kodak's retail outlets and independent retailers in the same market area. Id. at p. 12,507. No reasons were advanced for the reversal other than the implied one that the Commission now intends to apply the proviso language of the statutes strictly. On remand of the Kodak case, the examiner found that Kodak's 35 wholly owned and controlled retail outlets located in leading citics throughout the United States did in fact compete with independent retailers in the sale of 163 types of price-fixed amateur photographic products manufactured by Kodak. Eastman Kodak Co., FTC Doc. No. 6040, Initial Decision of the Hearing Examiner, filed May 18, 1954, at 2,6 . But the examiner then proceeded to disregard the rule under which the case was remanded to him and readopted the Donbleday test.

The examiner's application of the Doubleday "capacity" test demonstrates its inconclusive nature and the ease with which it can be evaded by skilled operators. In support of his conclusion that the contracts were entered into by Kodak as manufacturer, the ex:aminer cited the fact that in 1951 "sales of respondent's fair traded products by its own outlet stores represent[ed] only about 3\% of the total sales of respondent's fair trated products." Id. at 7. On appeal from the examiner's decision, the Government argued that the total sales by Kodak's retail outlets in 1952 represented more then $5 \%$ of respondent's overall sales and amounted to $\$ 33,124,035$, which probably made Kodak the largest single retailer of photographic products in the United States. Brief for Petitioner Supporting the Complaint, p. 25, Eastman Kodak Co., 3 CCH TRADE REG. REP. If 11,527 (FTC 1953). Thus it is apparent that the significance of any revenue breakdown is slight. The figtures can be made to support either side of the argument by selecting different years and shifting the context in which the figures are viewed.

Although no breakdown of Kodak's profits was in evidence, the examiner also argued that there was "such a preponderance of respondent's business in the manufacturing field that it is not reasonable to believe that its business or profits as a manufacturer have becn sacrificed in order to bolster its profits as a retailer." Eastman Kodak $\mathrm{Co}_{0}$, F'TC Doc. No. 6040, Initial Decision of the Hearing Examiner, at 20. However, since Kodak may have underestimated the elasticity of demand for its products, it may have raised retail markups without any belief that it was thereby sacrificing sales volume on the manufacturing level. The percentage of business on various levels of enterprise is hardly detcrminative of the crucial issue involved in the use of resale price maintenance by integratcd manufacturers: whether the firm has the power and incentive to integrate inefficiently.

The other indicia of Kodak's intent to contract as manufacturer adduced by the examiner seem even less convincing. He noted that the contracts recited that Kodak signed as manufacturer; that Kodak's retail outlets could "readily meet the lowest price any competitor could offer," so that Kodak used price maintenance only to protect the brand names of its manufacturered products; and that the contracts related only to particular Kodak products "rather than to all articles of the same general class regard- 
price maintenance by nonintegrated manufacturers would be necessary to deprive an integrated manufacturer of the benefits of Fair Trade. ${ }^{11}$

McKesson's insistence upon a factual showing of an additional restraint upon competition imposes an unjustifiable burden on the Government. Proof of specific intent to injure or actual injurious effect is no longer necessary to establish a violation of the antitrust laws, ${ }^{12}$ although either will support a finding that there has been such a violation. Contracts or agreements which merely create the power to injure competitors or the public at will are also illegal. ${ }^{13}$ Such power must be prohibited even though unexercised or exercised without any presently discernable injurious effect. If private parties are allowed to possess power to control the market, constant judicial

less of manufacturing source" Id. at 19-20. The form of the contracts assuredly should not control. American Tobacco Co. v. United States, 221 U.S. 106, 181 (1911). And the government's brief on appeal points out that the recital did not appear in Kodak's agreements until after the FTC had investigated the matter. Brief for Petilioner Stupporling the Complaint, p. 21, Eastman Kodak Co., 3 CCH Trape ReG. Rep. I 11,527 (FTC 1953). Secondly, there is no factual matter in the record to support the assertion that Kodak's retailers would benefit competitively from the abandonment of price maintenance on Kodak-manufactured goods. And see text at notes 12-18 infro. Finally, invalid "horizontal" agreements need not concern more than one product of one manuiacturer. United States v. Masonite Co., 316 U.S. 265 (1942).

11. The opinion is not without ambiguity on this point. In one place the court speaks of the necessity of a showing of "some injury, inchoate or consummate, to competition." United States v. McKesson \& Robbins, Inc., 122 F. Supp. 333, 337 (S.D.N.Y. 1954) (emphasis added). Nevertheless, it is apparent that the .IIcKesson court was calling for a factual showing of an actual injury or intent to injure. See id. at 338 (factual showing of illegality necessary); id. at 339 (factual showing that manufacturer became a wholesaler with intent to gouge consumers an example of illegality); ihid. (bare assertion that the mere existence of price-fixing induces competing wholesalers to buy from MIcKesson rather than from other manufacturers not a prima facie factual showing of illegality absent some factual showing that such is the case).

12. "[E]ven if we assume that a specific intent to accomplish [the prohibited] result is absent, [defendant] is chargeable in legal contemplation with that purpose since the end result is the necessary and direct consequence of what he did." United States v. Griffith, 334 U.S. 100, 108 (1948). Accord, United States v. Patten, 226 U.S. 525, 543 (1913); United States v. Paramount Pictures, Inc., 334 U.S. 131, 173 (1948); United States : Masonite Corp., 316 U.S. 265, 275 (1942).

"The power to fix prices, whether reasonably exercised or not, involves power to control the market and to fix arbitrary and unreasonable prices .... Agreements which create such potential power may well be held to be in themselves unreasonable or unlawiul restraints ... . That such was the view of this Court in deciding the Slandard Oil and Tobacco cases, and that such is the effect of its decisions both before and after those cases, does not seem fairly open to question." United States v. Trenton Potteries Co., 273 U.S. 392, 397-98 (1926). See also United States v. Míasonite Corp., 316 U.S. 265, 281-82 (1942) ; United States v. Socony-Vacuum Oil Co., 310 U.S. 150, 225 n.59 (1940). Cf. American Tobacco v. United States, 32S U.S. 781, 810-11 (1946); Unitcd States v. Griffth, 334 U.S. 100, 107-09 (1948); United States v. Paramount Pictures, Inc., 334 U.S. 131, 173 (1948).

13. See, generally, Rostow, The New Sherman Act: A Positive Instrumcnt of Progress, 14 U. CHI. L. Rev. 567 (1947). 
supervision of the reasonableness of their actions would be necessary. ${ }^{14}$ And this would inevitably lead to administrative control of the industry by a public agency. ${ }^{15}$ Moreover, it would be impossible to determine the reasonableness of the decisions made by those in command of the market even if such regulation by the Government could be avoided.10 The fundamental premise of our national policy is that competition rather than courts, administrative agencies, cartels, or monopolists should be relied on to direct the operation and development of our economy. ${ }^{17}$ Therefore, the only meaningful standard for economic conduct is that it stand the test of competition in a free market.18

The principle that marketing devices which are not illegal in themselves become illegal when they create the powver to override the market has been applied to those areas of our economy in which Congress has allowed monopoly power to exist. ${ }^{10}$ The courts have refused to permit holders of legal monopoly power to utilize contractual arrangements which would enable them to exploit or extend their power beyond the specific exemption from the general rule of competition. ${ }^{20}$ Thus, in United States $v$. Griffith, ${ }^{21}$ the defendant was enjoined from purchasing motion pictures on a circuit-wide basis because of the defendant's monopoly position in some of the towns in which it owned theatres. No proof was required that independent exhibitors had actually been injured by Griffith's use of a single contract for its entire circuit. ${ }^{22}$ The Supreme Court condemned the practice because it created

14. See United States v. Trenton Potteries Co., 273 U.S. 392, 397 (1927) (dictum); United States v. South-Eastern Underwriters Ass'n, 322 U.S. 533, 536 (1944) (same).

15. Rostow, supra note 13, at 573. Cf. Fashion Originators' Guild of America, Inc. v. FTC, 312 U.S. 457, 465-66 (1941) ; Addyston Pipe \& Steel Co. v. United States, 175 U.S. 211,242 (1899).

16. See United States v. Trenton Potteries Co., 273 U.S. 392, 398 (1927) (dictum); United States v. Masonite Corp., 316 U.S. 265, $281-82$ (1942) (same). Cf. the opinion of Judge Taft in United States v. Addyston Pipe \& Steel Co., 85 Fed. 271, 283-84 (6th Cir. 1898).

17. See Standard Oil Co. v. FTC, 340 U.S. 231, 248-49 (1951) (dictum); United States v. Crescent Amusement Co., 323 U.S. 173, 187 (1944) (same); Standard Oil Co. v. United States, 221 U.S. 1, 65 (1911) (same). See also Rostow \& Sachs, Entry Into the Oil Refining Business: Vertical Integration Re-Examined, 61 YALE L.J. 856, 864 (1952).

18. For recent justifications of the longstanding public policy favoring competitive markets as the regulators of our economy and for refutations of its divergent modern critics, see Loevinger, Antitrust and the New Economics, 37 Mrns. L. Rev. 505 (1953); Bowman, Tozvard Less Monopoly, 101 U. PA. L. REv. 577 (1953).

19. See, generally, Schueller, The Neze Antitrust Illegality Per Se: Forestalling and Patent Misuse, 50 CoL. L. Rev. 170 (1950); Comment, Vertical Forestalling Under the Antitrust Lazes, 19 U. CEr. L. Rev. 583 (1952).

20. United States v. Line Material Co., 333 U.S 287, 300 (1948); United States v. Masonite Corp., 316 U.S. 265, 277 (1942); Ethyl Gasoline Corp. v. United States, 309 U.S. 436, 456-57 (1940).

21. 334 U.S. 100 (1948).

22. "What effect these practices actually had on competitors of appellee exhibitors or on the growth of the Griffith circuit we do not know." United States v. Griffith, 334 U.S. 100,109 (1948). 
the power to obtain advantages for the corporation's theatres in the nonmonopoly towns which were unrelated to the competitive efficiency of those theaters. ${ }^{23}$ Attempts to tie a nonpatented commodity to the sale of a patented one have been dealt with in a similar fashion. ${ }^{24}$ No proof of actual injury to firms producing goods which compete with the unpatented, tied-in commodity has been required because such tie-in contracts create the poizer to inflict such injury. ${ }^{25}$

The use of resale price maintenance by an integrated manufacturer generates a power to injure competitors and consumers beyond the scope of the restriction on competition expressly sanctioned by Congress. The nonintegrated manufacturer's resale price is normally geared to the marketing costs of the independent resale outlet of average efficiency. ${ }^{-0}$ This assures the manufacturer optimum distribution at the optimum price. ${ }^{2 \pi}$ However, when an integrated producer sets resale prices, the selling costs of the manufacturer's own outlets may become an important additional element of price determination. ${ }^{28}$ If his outlets are inefficient, the cost of this inefficiency may be reflected in a higher resale price fixed for his commodity because resale price maintenance gives him the power to insulate his outlets from the inroads of more efficient competitors. The manufacturer can effectively prevent price cutting on his own product by virtue of the new power against nonsigners granted by the McGuire Act. ${ }^{29}$ Furthermore, the integrated manufacturer can count on similar upward price revisions by producers of like commodities. For the core of the matter is that manufacturers ordinarily use resale price maintenance only in those industries in which there is a high degree of price parallelism. ${ }^{30}$ In industries in which the price structure

23. "The consequence of such a use of monopoly power is that films are licenced on a non-competitive basis in what would othervise be competitive situations." Id. at 108.

24. See, e.g., International Salt Co. v. United States, 332 U.S. 392 (1947); Mercoid Corp. v. Mid-Continent Investment Co., 320 U.S. 661 (1944) ; Motion Picture Patents Co. v. Universal Film Mfg. Co., 243 U.S. 502 (1917).

25. In International Salt Co. v. United States, 332 U.S. 392 (1947), appellant's leases of its patented machines contained a provision requiring lessees to use only appallant's salt products therein. Appellant contended that summary judgment was unauthorized beeause it precluded trial of alleged issues of fact as to whether the restraint was unreasonable within $\S 1$ of the Sherman Act or substantially lessened competition or tended to create a monopoly in salt within $\$ 3$ of the Clayton Act. But the Court said: "We think the admitted facts left no genuine issue ...." Id: at 396 .

26. See FTC REPort 127, 129; Fulda, Resale Price Mainterance, 21 U. Cmi. L. Rev. $175,189,191$ (1954).

27. 54 CoL. I. REv. 282, 285 (1954).

28. Cf. United States v. Paramount.Pictures, Inc, 334 U.S. 131, 147-4S (1948).

29. See note 5 supra. Recent Congressional validation of state nonsigner provisions as applied to sales in interstate commerce may account for the newly developed attack on the use of price maintenance by integrated manufacturers.

30. Resale price maintenance was designed in part to protect investment in the good will symbolized by brand names against the depreciation which might result from loss- 
is not "sticky," a resale price agreement is merely an unwelcome device which hinders distributors in meeting constantly fluctuating price levels and consequently results in a loss of sales and profits.

The scope of the potential injury is wider than an increase in retail prices to consumers. The availability of resale price maintenance is a powerful incentive to forward integration as well as a technique for protecting inefficient outlets already in operation. ${ }^{31}$ In turn, the manufacturer's construction or purchase of additional outlets eliminates, pro tanto, both existing and potential independent competing distributors. ${ }^{32}$ Finally, the producer's newly acquired outlets will enhance his market position on the manufacturing level by reason of his growing command of the channels of distribution. ${ }^{33}$ McKesson's requirement of an evidentiary showing of these effects would ordinarily be incapable of fulfillment. ${ }^{34}$ The court should have recognized the principle that the power to bring about a prohibited effect is sufficient to invalidate a marketing device and it should have held that the power of manufacturerdistributors to utilize resale price maintenance as an umbrella over inefficient

leader selling. Investment in brand name development is most prevalent where a few manufacturers control significant fractions of the market and produce commodities which are close but not perfect substitutes. Where such a "differentiated oligopoly" exists, independent price determination tends to be discouraged. BAIN, PRICE THEORY 276 (1952). Price competition will then be susperseded by nonprice rivalry, a less expensive method of dividing the market. Id. at 311. See also Comment, 19 U. Cin. L. Rev. 583, 598 (1952) ; FTC REPORT lvi, 1xi, 1xii.

Furthermore, price leadership has proved virtually uncontrollable under the Fair Trade laws. The Act's condernnation of "horizontal" agreement has been repeatcdly circumvented. Hearings before a Subcommittee of the House Committec on Intcrstatc and Foreign Commerce on H.R. 5767 (McGuire Act), 82d Cong., 2d sess. 259 (1952); Hearings before the Antitrust Subcommittee of the House Committee on the Judiciary on Resale Price Maintenance, 82d Cong., 2d sess. 97-99 (1952) ; FTC REPORr, 1x-lxii, 545. The only other statutory weapon available against collusion is the requirement that pricefixed commodities be in "free and open competition with commodities of the same general class produced or distributed by others." See statutes cited note 2 supra. It has rarcly been successfully invoked. Fulda, supra note 26 , at 197-98; 1 CCH TRADE REG. REv. if 3154 (1954).

31. Certainly operating outlets producing assured revenue of, say, $15 \%$ constitute more attractive investments for surplus corporate capital than securities which may yield a maximum average of $8 \%$. The present drive among corporations for diversification is evidence of the existence of surplus corporate capital and the general recognition of the profitability of investment in going businesses rather than in securities. See U.S. News \& World Report, Aug. 13, 1954, pp. 68, 71.

32. Yet an important purpose of Fair Trade is the protection of small, individual entrepreneurs from the incursions of larger, wealthier distributors. See note 41 infra.

33. Cf. Dirlam \& Kahn, Fair Competition: The Law and Economics of AntiTRUST POLICY 142 (1954).

34. See the discussions of evidentiary problems involved in antitrust litigation in Dession, The Trial of Economic and Technological Issues of Fact, 58 YALE L.J. 1019, 1242 (1949); McAllister, The Big Case: Procedural Problems in Antitrust Litigation, 64 Harv. L. REv. 27 (1950). 
forward integration is sufficient to warrant condemnation of the use of the device by such firms. ${ }^{35}$

This analysis, however, does not justify the application of a per se rule in this area. ${ }^{36}$ An integrated firm will derive no illicit power from its use of resale price maintenance if the firm is in an industry in which pricing practices on the manufacturing level are highly competitive. In such an industry there is no price leverage which the integrated firm can use to expand inefficiently, because a rise in price will result in reduced profits due to a loss of

35. Cf. Dirlans \& KaHN, op. cit. supra note 33, at 142-43: "The only condition necessary for integration to raise the possibility of abuse is the existence of substantial imperfections of competition in some of the fields in which an integrated company operates. The very fact that a company sells in a number of markets, or fulfills a number of funetions, in some of which it is subjected to weaker competitive pressures than in others, gives it a leverage and a staying power in its more highly competitive operations that have nothing to do with its relative efficiency there ... . [I]ntegration that links together competitive areas with others in which competition is already seriously defective accomplishes by financial consolidation something very much like what is accomplished by the tie-in prohibited by Section 3 of the Clayton Act: it permits the use of market power in one area to create competitive advantages unrelated to efficiency in others."

36. But a majority of the FTC has already adopted such a rule, contingent only on a finding of "actual" competition between the integrated manufacturer's outlets and the outlets bound by the Fair Trade agreement. Eastman Kodak Co., 3 CCH TENIE REE. REP. If 11,527 (FTC 1953).

And the Supreme Court may have embraced the per se rule in United States v. Masonite Corp., 316 U.S. 265 (1942). There, defendant MFasonite, a manufacturer of a patented hardboard used in the building trade, executed del credere "agency agreements" for the sale of his product, reserving the right to fix the resale price. Defendant "agents" were engaged either in manufacturing and selling building materials, or in selling building materials manufactured by others. Both "principal" and "agent" maintained selling organizations and to a large extent competed in the same markets. Holding the arrangement to be an illegal price-fixing conspiracy the Court said: "[W]hen it is clear ... that the marketing systems utilized by means of the del cridere agency agreements are those of competitors of the patentee and that the purpose is to fix prices at which the competitors may market the product, the device is without more . . a violation of the Sherman Act" Id. at 279. The Supreme Court found no authorization of such a scheme in the Miller-Tydings Act. Id. at 279 n.4.

The McKesson court distinguished Masonite. It said the latter case did not involve Fair Trade agreements, "but rather a familiar attempt by a patentec, through agency and licensing arrangements, to extend a patent monopoly beyond the linits of the patent and anti-trust statutes." United States v. MIcKesson \& Robbins, Inc, 122 F. Supp. 333, 339 (S.D.N.Y. 1954). But the patent question was raised only as a matter of defense to the government's underlying charge of illegal price-fixing. United States v. Masonite, supra at 276. And the Supreme Court disposed of the contention by noting that a patentee had no more right to construct illegal combinations between competitors than the owner of an unpatented commodity. Id. at 279. The MfcKesson court also argued that "even considered as fair trade agreements a sufficient factual showing of illegality existed because several competing manufacturers, unrelated as buyers and sellers, agreed upon prices at which the product of one such manufacturer should be sold in competition with that of the others." United States v. McKesson \& Robbins, supra at 339. The Supreme Court, however, said that the presence of competing patents served mercly to accentuate the evil condemned, vis., the regimentation of competing marketing systems by Masonite through price-fixing. United States v. MFasonite Corp., supro at 279, 281. 
its customers to other manufacturers. ${ }^{37}$ Since Fair Trade is ordinarily found only in industries in which there is no active price competition between mant1facturers, ${ }^{38}$ use of the device by a manufacturer-distributor should be prima facie unlawful. But an integrated firm should be allowed to prove as an affirmative defense that price competition within its industry is sufficiently intense to prevent its use of Fair Trade to preserve or expand inefficient outlets. ${ }^{39}$

The Supreme Court has emphasized that resale price maintenance is a privilege, restrictive of a free economy, which should be limited to the purposes for which it was clearly intended. ${ }^{40}$ Fair Trade was enacted to enable manufacturers to protect their investment in brand name development from the depreciation caused by loss-leader selling and to safeguard small independents from the competitive advantages of large chain distributors. ${ }^{41}$ The evidentiary requirements of $M c K e s s o n$ will encourage manufacturers, under the guise of brand name protection, to preempt the field of distribution from

37. Cf. DirLaAs \& KanN, op. cit. stipra note 33, at 146-47: "[T] re root cause of inequity and possible monopoly power issuing from integration is the imperfection of competition in the less workably competitive field that the integrated firm operates in, rather than the integration that ties this operation to others. It is the absence of competition in the supply of telephone service that confers on Western Electric the power to exploit telephone subscribers and to carry on unfair competition in unsheltered markets. With pure competition in the telephone business, there would be no cause for concern about vertical integration."

38. See note 30 supra, and accompanying text.

39. Advocates of Fair Trade have pointed to certain items in which price competition is said to be brisk. Hearings before a Subcommittee of the House Commiltec an Interstate and Foreign Commerce on H.R. 5767 (McGuire Act), 82d Cong., $2 \mathrm{~d}$ sess. 22-23 (1952) (e.g., electric toasters, face powder).

The term "price competition" is not used herein as the equivalent of the statutory phrase "free and open competition," nor has the latter phrase been interpreted to include the former. 1 CCH TrAde Reg. Rep. $\llbracket 3154$ (1954); Fulda, Resale Price Maintenance, 21 U. CHI. L. REv. 175, 197-98 (1954). Active price competition should be an additional prerequisite to resale price-fixing by integrated firms.

40. Schwegmann Bros, v. Calvert Distillers Co., 341 U.S. 384, 389-90, 395 (1951). Cf. United States v. Masonite Corp., 316 U.S. 265, 280 (1942).

An interesting parallel can be drawn between the Schreggmam case, supra, and the present problem in the matter of the construction of the language of the Fair Trade laws. In Schwegmann the question was whether the Miller-Tydings Act, which legalized price maintenance "contracts or agreements" already lawful under state law, included within its purview state nonsigner provisions. The Court held that it did not since the Act spoke only in terms of consensual agreements, references to nonsigner provisions being meticulously omitted. The last phrase of the proviso in the Federal Acts, disaliowing contracts or agreements "between persons, firms or corporations in competition with each other," has apparently never been included in any of the state statutes. As to the preceding part of the clause, the state and federal laws are ordinarily identical. 2 CCH TRADE REG. REP. II 10,000-15,520.10 (1954). Thus, applying the converse of the rule in Schwcgmanm, it would seem that meticulous inclusion of the phrase indicates that Congress intended a more rigorous prohibition of "horizontal" agreements than that fotund in state statutes.

41. See United States v. Mickesson \& Robbins, Inc., 122 F. Supp. 333, 338 (S.D.N.Y. 1954) ; 54 CoL. L. REv. 282, 284-85 (1954). 
efficient independents. And it will allow them to injure consumers to a greater degree than that clearly authorized by Congress. ${ }^{22}$ The proposed doctrine of prima facie illegality would preserve the dual function of Fair Trade and would more effectively protect the interests of consumers, independent distributors, and independent manufacturers.

42. See text at notes 26-30 supra. Cf. 54 CoL. L. REv. 282, 285 (1954). 